\title{
TRADIÇÕES DISCIPLINARES E TRADIÇÕES INTELECTUAIS NA TRAJETÓRIA DA CIÊNCIA POLÍTICA BRASILEIRA
}

\author{
Fernando Leite*
}

\begin{abstract}
O artigo trata do papel de tradições disciplinares e intelectuais na constituição da Ciência Política brasileira. Objetiva-se identificar as tradições que influenciaram as visões de grupos de intelectuais, sociólogos e cientistas políticos responsáveis pelos princípios que estruturaram a produção atual da disciplina. A partir de entrevistas e referências bibliográficas, identificamos tradições e suas oposições. Entendemos que a adesão e a incorporação desta ou daquela tradição pelos grupos envolvidos dependeram de suas trajetórias acadêmicas, marcadas por oposições orientadas no sentido de definir a disciplina, isto é, definir seu objeto legítimo e as abordagens consideradas mais apropriadas para estudá-lo. A produção dependeu de três grupos e visões: (i) humanística, associada aos intelectuais que estudavam temas políticos antes da institucionalização da Ciência Política; (ii) acadêmico-societal, associada à "escola sociológica paulista" e (iii) científico-politológica, associada ao grupo constituído em torno da UFMG e do Iuperj responsáveis pela institucionalização da Ciência Política no Brasil.

Palavras-chave: Ciência Política brasileira. Cientistas sociais. Produção acadêmica. Tradições disciplinares. Tradições intelectuais.
\end{abstract}

\section{INTRODUÇÃO1}

A produção de conhecimento sobre a produção erudita poderia ser, por si só, um fim em si mesmo. Por um lado, reconstruções da história de uma disciplina são importantes aspectos de maturidade intelectual e contribuem para a consagração de identidades disciplinares, das quais depende seu reconhecimento dentro e fora do campo acadêmico. Por outro, as disciplinas estão imersas ou constituem campos aos quais também se aplicam princípios atuantes em outros campos. Sua história, seu arranjo institucional e sua estrutura de relações também condicionam suas práticas particulares, além de suas ideias e o conhecimento aí produzido.

Muitos são os benefícios de uma abordagem reflexiva sobre o campo acadêmico. Uma sociologia histórica de uma disciplina,

\footnotetext{
* Universidade Federal do Paraná (UFPR). Núcleo de Pesquisas em Sociologia Política Brasileira (NUSP).

Rua XV de Novembro, 1299. Cep: 80060-000. Centro Curitiba - Paraná. ferngutz@gmail.com

${ }^{1} \mathrm{~A}$ pesquisa que deu origem a este trabalho foi financiada pela Coordenação de Aperfeiçoamento de Pessoal de Nível Superior (Capes). Agradeço aos pareceristas anônimos de Caderno CRH por suas sugestões.
}

em particular, pode desvelar e contribuir para controlar suas condições de produção. Conhecer as forças que condicionam as ideias contribui para desenhá-las de modo a atribuir mais autonomia ao conhecimento e igualdade de oportunidades entre aqueles que pensam, escrevem e falam.

A Ciência Política brasileira é um caso curioso. Em primeiro lugar, tem-se um rápido processo de autonomização disciplinar, com a multiplicação de programas de pós-graduação, institucionalização de áreas temáticas e o crescimento de certas abordagens. Nesse sentido, Leite (2015) mostrou que a produção está estruturada em torno de tradições disciplinares e tradições intelectuais. Uma tradição é um conjunto mais ou menos coeso de ideias e hábitos de pensamento historicamente persistentes. Fundamentalmente, constitui um conjunto de disposições mentais que fornecem parâmetros gerais de interpretação do real. Entre as tradições disciplinares, a maior parte do campo divide-se entre tradições "politológicas", que tratam da política institucional," "societais",

${ }^{2}$ Arranjo de organizações responsáveis pelo exercício legítimo do poder político (poder sobre as outras formas de 
que lidam com algum fenômeno político externo, ou tratam-na como um âmbito dependente, e "estatais", que estudam algum órgão estatal, à exceção da politica institucional. Em torno delas orbitam tradições "econômicas", que lidam com fenômenos externos de natureza econômica, como a econometria ou a economia política, e "ideais", que estudam fatos de natureza linguístico-ideal, como no contextualismo linguístico. A parte mais importante do campo, entretanto, divide-se entre as tradições politológicas e societais.

Entre as tradições intelectuais, há uma grande oposição entre uma tradição "científica" e outra "humanística". Essa oposição engloba oposições mais específicas: entre objetos empíricos e teóricos; métodos quantitativos e qualitativos; entre os estilos erístico e matemático, de um lado, e literário e militante, de outro $^{3}$; e entre trabalhos mais e menos "positivistas", isto é, que empregam estatísticas mais sofisticadas, apresentam e testam hipóteses e envolvem argumentos causais, de um lado, e que não o fazem, de outro.

Mas, além disso, tivemos também o estabelecimento de novos critérios de avaliação, como o Qualis, ${ }^{4}$ que passaram a influenciar a hierarquia da produção. Em particular, por suas propriedades, entre elas as áreas e abor-

poder), incluindo instituições informais em prática nesse arranjo. É demarcada pela competição pela posse de posicões governamentais e pelo controle dos recursos sob a tutela do governo, bem como a deliberação em torno de \&े sua aplicação em forma de políticas públicas. Ela inclui o s voto e formas institucionalizadas de participação.

: ${ }_{0}^{1}{ }^{3}$ Um estilo cognitivo é uma forma de perceber, interpretar I. e transmitir informação, uma forma de compreensão e de œ comunicação (Kaplan, 1964, p. 33). Leite (2015, p. 167) identificou seis estilos na produção contemporânea da

2. Ciência Política brasileira: literário, acadêmico, erístico, $\stackrel{\infty}{\wedge}$ simbólico e militante.

- ${ }^{4}$ No Brasil, a Coordenação para o Aperfeiçoamento de Pesస soal de Ensino Superior (Capes) é a agência federal res-

$>$ ponsável por fixar as regras de avaliação dos programas

ث de pós-graduação. Parte importante da avaliação refere-se

à quantidade e à qualidade das publicações. A qualidade

das publicações é medida a partir de um sistema de ava-

liação de periódicos, denominado Sistema Qualis, no qual

cada área de conhecimento distribui os periódicos nacio-

nais e estrangeiros nos seguintes estratos: A1, A2, B1-B5

e C. Já faz algum tempo que a produção qualificada na

área de Ciência Política é definida como aquela publicada

exclusivamente em periódicos A1, A2 e B1. Na referência

citada (Leite, 2015), foram considerados todos os periódi-

cos nacionais desses estratos, num total de 23 periódicos. dagens associadas às tradições politológicas e "científicas" são mais valorizadas.

Coloca-se, então, a questão: por que essas são as tradições mais valorizadas? Como o campo assim se constituiu?

As tradições disciplinares e intelectuais que hoje organizam o campo, em particular as oposições entre politológico e societal, empírico e teórico e científico e humanista, constituem formas concorrentes de definir o objeto legítimo de investigação (definir "político") e as abordagens mais adequadas para estudá-lo (teorias, métodos, premissas etc.). Em outras palavras, constituem visões disciplinares concorrentes. Essas visões têm ligações históricas com certos grupos que, por meio de sua atividade acadêmica e de seus embates, definiram os parâmetros do campo no qual a Ciência Política se institucionalizaria, estruturando sua produção.

Este artigo explora esse processo a partir dos seguintes eixos: (i) relações entre os principais grupos envolvidos direta e indiretamente na criação da disciplina e, através delas, (a) as relações de influência e conflito com disciplinas vizinhas e (b) as relações entre modelos de atividade intelectual, idealmente tipificados nas figuras do scholar (cientistas mineiros e cariocas), do acadêmico (sociólogos da Universidade de São Paulo) e do erudito-polímata (intelectuais do Instituto Superior de Estudos Brasileiros e intelectuais precursores); (ii) fatores contextuais, como influências políticas, a atuação de agências de fomento e a reforma universitária de 1968. A articulação entre esses fatores alocou grupos e ideias organizados em visões disciplinares favoráveis ou desfavoráveis às tradições que hoje estruturam a produção.

\section{A INFLUÊNCIA DO MODELO HU- MANÍSTICO: intelectuais e intérpre- tes do Brasil}

O modelo humanístico foi proeminente entre os "intelectuais" brasileiros que dominaram os estudos políticos até a década de 1960, 
período que podemos dividir em duas fases: (i) "pensadores" desvinculados de instituições acadêmicas, como Oliveira Vianna, Francisco Campos, Alberto Torres, Azevedo Amaral, Nestor Duarte, Pontes Miranda, Victor Nunes Leal, entre outros, usualmente reunidos sob a alcunha de "pensamento político brasileiro", proeminentes até a década de $1930^{5}$; (ii) o círculo da intelligentsia carioca, centralizada no Instituto Superior de Estudos Brasileiros (ISEB) e corporificada nas carreiras e personalidades de Hélio Jaguaribe e Evaristo de Moraes Filho, durante os anos 1950 e 1960.

Tratou-se de um período cujo estilo baseava-se em "amplos ensaios histórico-sociológicos” produzidos em regime individual e não profissional (Lamounier 1982, p. 413), em "modalidades de representação do mundo político e social tidas como pré-científicas" (Lessa, 2011, p. 20-21), em particular pelas ciências sociais desenvolvidas na USP a partir da década de 1950, e pelos cientistas políticos do eixo UFMG-Iuperj, a partir da de 1960 - e seu corolário, a visão disciplinar politológicocientífica, hoje dominante. Outro aspecto importante é a indiferenciação e o hibridismo: os estudos misturavam narrativas históricas, literárias, filosóficas, sociológicas, econômicas, etc. (Lessa, 2011, p. 27-28).

Ao mesmo tempo, esses estudos abriram precedentes para a tradição politológica contemporânea, em um processo que Lamounier (1982) considerou um resgate e Brandão (2005) a continuação de uma linhagem. Grande parte desses estudos lidou com o problema da construção do Estado nacional, julgado fundamental para a construção da "nação" brasileira; talvez a principal preocupação dos intelectuais à época, reunidos em torno da "questão nacional" (Oliveira, 1990). Victor Nunes Leal, sobretudo, foi pioneiro ao estudar instituições propriamente políticas. Entre alguns focos de atenção, tem-se “[...] centralização ou descentralização política, prerrogativas do Poder Moderador, reforma

${ }^{5}$ Para um levantamento bibliográfico extensivo, consultar Santos (2002) e Villas Bôas (2007). eleitoral, abolição, propriedade fundiária, papel das forças armadas e forma de governo, entre outros” (Lessa 2011, p. 30). A Ciência Política retomaria esses objetos, porém com um estilo mais "científico". No entanto, não há um enfoque específico e sistemático sobre a autonomia das instituições políticas, que estão enredadas em uma teia de fatores de ordens diversas.

Assim, do ponto de vista dos atuais mecanismos de estratificação, esse pensamento ganha valor por envolver instituições políticas e perde valor por envolver fatores de âmbitos extrapolitológicos e por não seguir um estilo mais "científico", positivista.

\section{Eruditos e polímatas no Brasil}

Em vez de especialistas ou profissionais, esses intelectuais são, antes de tudo, eruditos, polímatas a meio-caminho entre a filosofia, as letras e a política (Jackson, 2007a, p. 120-121; Miceli, 2001b, p. 24-25). Poucos documentos são tão valiosos para expressar o habitus desse grupo como a entrevista de Evaristo de Moraes Filho concedida a Hiro Barros Kumasaka e Luitgarde Barros, em 8 de março de 1988. A certa altura, a entrevista passa a versar sobre a história do antigo Instituto de Ciências Sociais (ICS) da Universidade Federal do Rio de Janeiro (UFRJ), abordando as características, a personalidade e os destinos de alguns de seus quadros. Evaristo é indagado sobre Rui Coelho, enunciando, do estilo ao conteúdo, os alicerces dessa figura iantelectual:

Luitgarde - No caso da resposta do professor Rui Coelho, trata-se então de um erudito e não de um professor. Não lhe parece?

Evaristo - Não. Nada impede que o professor seja um erudito ou que um erudito seja professor. Uma mesma pessoa pode fazer mais de um curso superior ou dedicar-se a mais de um campo de estudos, para não chegar àquele caso extremo do especialista, que sabe cada vez mais de cada vez menos... Eu próprio, para dar meu exemplo - sempre antipático, segundo Pascal... - fiz os cursos de Direito e de Filosofia. Nesses cursos tive oportunidade de estudar 
não só filosofia propriamente dita como: Psicologia, Lógica, Estética, Ética, Economia, Sociologia, Psicologia Educacional, Administração Escolar, Didática Geral e Especial. O universo de interesses foi bem amplo (Kumasaka; Barros, 1988a, p. 26).

Além do rol aristotélico de assuntos levantados, repare-se, por exemplo, a estratégica passagem "sempre antipático, segundo Pascal...”. Uma referência filosófica clássica é inserida em uma proposição subjetiva e antitética, demonstrando um misto de ironia e erudição, ressaltando-se a própria personalidade e assimilando capital simbólico. O eu associase à excepcionalidade - e a excepcionalidade adquire traços de rebeldia, catalisando-a. São propriedades muito valorizadas nesse modelo de atividade intelectual. Além de tornar explícita a sua antítese, a figura do scholar e o modelo científico mais ortodoxo, a passagem também manifesta outra propriedade típica desse modelo: a alta exigência de recursos e distanciamento, de skholè, constituindo uma espécie de aristocratismo cultural, celebrado durante o período renascentista e parcialmente dissimulado no campo das ciências sociais. A maior parte dos "intelectuais" e "pensadores”, podendo-se, aliás, regredir até a Antiguidade, tem essa propriedade em comum - e ela é fundamental para a afirmação daqueles que o encarnam: a erudição é o assimilador do capital simbólico mobilizado nas estratégias de ญ्ष distinção e afirmação no campo intelectual. ${ }^{6}$ Isso esclarece a razão de - até o estabelecimenis pos subalternos.

${ }^{7}$ Para as origens sociais dessa geração, cf. Kumasaka e Barros (1988a, p. 6-7, 1988b, p. 1-7); Arruda (2001, p. 168174); Miceli (2001b, p. 103-132); Castro e Oliveira (2005, j p. 178-182); Jackson (2007b, p. 34-37), entre outros. uma figura mais específica que, ainda eclética, é mais atraída pelo ensaio teórico e pela Filosofia. Há mais unidade por parte da abordagem baseada em sistemas filosóficos, que é, então, aplicada a objetos de disciplinas das mais diversas.

Hélio Jaguaribe é a personificação desse tipo. Forma-se em Direito, inscrevendo-se no padrão de cientistas sociais da primeira metade do século XX, oriundos das classes dominantes. Intelectualmente, começa marxista, assimila o historicismo neokantiano e, finalmente, a "teoria crítica", que o permite reunir marxismo e historicismo (Kumasaka; Barros, 1988b, p. 3). Representa e defende uma visão de ciência social indiferenciada, entre Letras, Economia, Sociologia, Filosofia e Política, e concomitantemente à imagem de Sartre, destaca a figura do intelectual total engajado, em uma simbiose de cultura e política. Assim como o caso de Evaristo, algumas passagens expressam um tipo ideal materializado:

Hiro - Mas o senhor exerceu Direito, isso é que espantou nessa entrevista.

Hélio Jaguaribe - É verdade. Veja bem, a colocação é incorreta. Deveria dizer que, no período que precedeu meu ingresso à Universidade, eu ainda não tinha uma preocupação com consciência social. Comecei a vida intelectual pensando que iria ser escritor e voltaria um pouco para a poesia e para a coisa literária. No final da adolescência esse interesse transformouse em interesse filosófico. Confesso que, no fundo, eu sou um filósofo e espero voltar a uma cogitação filosófica nos anos de minha velhice. Mas circunstâncias várias, problemas no Brasil, desafio da compreensão de por que nós funcionamos mal (como quem nasce em uma família de loucos tem tendência para ser psiquiatra, quem nasce em sociedade subdesenvolvida e está angustiado com isso, tem tendência à ciência social), isso me levou, a partir da minha formação jurídica - que, naquele tempo, muito mais que hoje, era muito sociológica - a entrar na ciência social. [...]. (Kumasaka; Barros 1988b, p. 25-26)

Os alicerces desse modelo humanístico são particularmente evidentes no pensamento de Guerreiro Ramos, figura central do ISEB. Ramos é fortemente influenciado pelo idealismo alemão e o romancismo francês, herdando sua concepção espiritualista de "cultura": 
Para Guerreiro a cultura é um princípio espiritual da vida humana e se contrapõe à ideia de civilização que expressa seus aspectos temporais e materiais. A cultura é expressão da pessoa e esta se define por sua espiritualidade. O fim do homem é seu aperfeiçoamento moral e neste sentido a verdadeira cultura não é uma técnica e sim uma categoria do ser. (Oliveira, 1990, p. 21)

A "categoria do ser" é um dom, uma propriedade inata. Esse dom tem origem anímica. O intelectual, assim como o poeta da tradição idealista, é uma espécie de intérprete divino. Tem-se, aqui, um idealismo que retrocede a Platão, no sentido de que há um reino ideal acessível por faculdades espirituais e uma hierarquia entre essas faculdades: as mais elevadas são as reprodutoras da natureza das "Formas”. Em Platão, assim como em Descartes, a faculdade racional é a mais elevada. A poesia e a pintura são referidas ao "desejo" e tratadas como imitações, representações deturpadas não apenas das "Formas", mas dos objetos materiais (Papas, 2015, p. 11-17). Já o idealismo alemão alçaria a arte ao maior dos patamares, acima, inclusive, do conhecimento racional. A arte não apenas se expressa de uma forma sensível, mas é a própria atividade do "Absoluto” (Mondin, 2006, p. 168). A aproximação entre filosofia e literatura atinge o ápice com o romantismo e a ascensão do romance filosófico (Matos, 2013). Essa nova estética, entretanto, não abandona, mas aprofunda o espiritualismo. A proeminência da "alma racional" é substituída por outras faculdades mentais, em particular a intuição poética, que expressa verdades eternas de forma sensível. O intelectual e o poeta são porta-vozes dessa verdade - e das virtudes morais a ela associadas.

A cultura espiritual, expressão da pessoa, é também vista como a totalização dos anseios e idéias que residem no povo, mas que ele por si só é incapaz de se exprimir, cabendo aos gênios e sobretudo aos poetas esta faculdade. "A vocação é o elemento específico da pessoa, que torna todo homem original" [...] e "é a particularidade de cada pessoa que a torna só entre os homens". (Oliveira, 1990, p. 21-22)
Em outras palavras, essa superioridade espiritual torna o intelectual não apenas singular, único, insubstituível - propriedades valorizadas na tradição humanística -, mas capaz de representar a consciência coletiva.

\section{Efeitos sobre a Ciência Política brasileira}

Entre os vários efeitos exercidos sobre o campo da Ciência Política, podem-se destacar: - Criou antecedentes para o estabelecimento das tradições politológicas e estatais.

- Estimulou o desenvolvimento de abordagens linguístico-ideais na Ciência Política.

- Foi condição para as áreas contemporâneas de teoria política e história das ideias.

- Criou uma cultura de intervenção política que, sob premissas e abordagens distintas, encontraria eco nas tradições politológicas e societais, inclusive na USP, UFMG e Iuperj.

- Sacramentou a figura do intelectual brasileiro, inscrevendo-se na tradição humanística.

- Inibiu a institucionalização e a autonomia acadêmica das ciências sociais e, assim, da Ciência Política.

\section{A ACADEMIA ENTRE O HUMANISMO E A CIÊNCIA: tradições societais e cientistas sociais em São Paulo}

A tradição societal se preocupa com fatos agonísticos externos à política institucional. A tradição societal é parte do pensamento político e é tão antiga quanto os escritos sobre o poder político. Em Aristóteles, por exemplo, as chamadas "causas materiais" são parte da polis, compondo unidades familiares, classes sociais e recursos materiais, interagindo com ordens propriamente políticas descritas pela causa "formal", manifesta na constituição, e pela causa "eficiente", manifesta no legislador e no soberano (Miller, 2012).

Intelectuais precursores dos mais diversos matizes ideológicos, como Gilberto Freyre, 
Sérgio Buarque de Holanda, Caio Prado Júnior, Oliveira Vianna, Plínio Salgado, entre outros, trabalharam com objetos e discutiram fatores hoje considerados em estudos societais na Ciência Política, como grupos dirigentes e estruturas de poder, relações raciais, estratificação social, entre outros (Bastos et al., 2006, p. 409-424; Brandão, 2005). Sua abordagem humanística, o estilo literário, o ensaio teórico e o engajamento político encontram paralelo na periferia da Ciência Política brasileira e persistem em particular nos estudos sobre pensamento político-social brasileiro (Brandão, 2005; Schwarcz; Botelho, 2011). Também contribuiu, portanto, para o delineamento da tradição societal brasileira.

A tradição societal, entretanto, vinculase mais diretamente à Sociologia e aos estudos políticos que se institucionalizam a partir da década de 1930. Essas Ciências Sociais foram marcadas por uma concepção de conhecimento que oscilava entre os extremos humanístico e científico, com mais atração pelo primeiro. Os estudos societais até hoje retêm essas propriedades (Leite, 2015).

Podemos observar, de forma particularmente clara, a constituição desses polos nos casos da Escola Livre de Sociologia e Política (ELSP), fundada em 1933, e na Faculdade de o Filosofia, Ciências e Letras (FFCL), de 1934, : núcleo da Universidade de São Paulo, criada ญ no mesmo ano. ${ }^{8}$

$\therefore$ Rio de Janeiro, em 1935 criou-se a Universidade do Distrito Federal (UDF), por Anísio Teixeira, com participantes importantes como

İ A USP foi fundada a partir da união da Faculdade de Ciências, Filosofia e Letras com a Faculdade de Direito \& (1827), a Escola Politécnica (1894), a Faculdade de Farmácia e Odontologia (1898) e a Faculdade de Medicina (1912). Os anos de fundação foram retirados dos sítios das respectivas faculdades.
Gilberto Freyre, Sérgio Buarque de Holanda, Afonso Arinos, Artur Ramos, Afrânio Peixoto e vários intelectuais franceses (Arruda, 2001, p. 233-237) Em 1939, é criada a Faculdade Nacional de Filosofia, sucessora da UDF, da qual participam Artur Ramos, Guerreiro Ramos, Costa Pinto, Victor Nunes Leal e Evaristo de Moraes Filho. Ambas as iniciativas produziram contribuições intelectuais importantes (idem, p. 237), embora não tenham se estabelecido. Dignos de nota também são o Instituto Nacional de Estudos Pedagógicos (INEP), em 1937, e o Instituto Brasileiro de Geografia e Estatística (IBGE), em 1938. Também temos o Instituto Joaquim Nabuco (1949), em Recife, criado por Gilberto Freyre, um importante centro do pensamento social à época (Miceli, 2001a).

O modelo predominante nessas iniciativas, entretanto, é próximo ao humanístico e baseado na figura do polímata. Os casos da ELSP e da FFCL são centrais para se entender a complexificação da tradição societal que se incorporaria à produção da Ciência Política brasileira, ao mesmo tempo incorporando e renovando a tradição humanística e instituindo um modelo mais científico, dentro de parâmetros "positivistas".

A partir de 1939, sob a direção de Donald Pierson ${ }^{9}$ (Limongi, 2001; Peixoto, 2001) e inspirada no Departamento de Sociologia da Universidade de Chicago, a Escola Livre de Sociologia e Política foi pioneira ao trazer um modelo mais científico de atividade intelectual: pesquisa empírica, rigor metodológico e trabalho coletivo associado à especialização, com formação de grupos de trabalho, alocação de estudantes em temas componentes de uma pesquisa maior e integração com seminários e leituras. Além disso, os temas tinham orientação prática, inscrevendo o projeto em temas

${ }^{9}$ Donald Person (1900-1995) fez doutorado em Sociologia na Universidade de Chicago, onde foi orientado por Robert Park, expoente, à época, da abordagem hoje chamada de "interacionismo simbólico". Chegou ao Brasil em 1935, ficando dois anos na Bahia, pesquisando contatos raciais. A Bahia era considerara, pelos norte-americanos, um laboratório privilegiado de relações raciais no mundo. Pierson volta ao Brasil em 1939, agora como professor de Antropologia Social da ELSP, aqui ficando até 1959. 
socialmente relevantes, como a exclusão do negro, também com inspiração em Chicago. $\mathrm{O}$ foco sobre a pesquisa combinada com temas de apelo público manifesta o imperativo profissionalizante desse modelo: tratou-se de formar sociólogos profissionais (Limongi, 2001; Peixoto, 2001, p. 518-524).

Por outro lado, a ELSP oscilava entre empregar uma concepção de "político" em sentido amplo e focar a dimensão propriamente simbólica dos fenômenos sociais. Ela se dedicou aos chamados "estudos de comunidades", sobretudo de negros e de imigrantes, lidando com os fenômenos de "aculturação" e estratificação bem como condições de vida dos trabalhadores (Peixoto, 2001). Tratou-se, assim, de um modelo societal e científico, dentro de parâmetros de cientificidade empírico-indutivos.

A Faculdade de Filosofia, Ciências e Letras, núcleo da Universidade de São Paulo então em constituição, distinguiu-se por ser uma iniciativa privada das elites econômicas e culturais paulistas, interessadas em restituir a hegemonia do estado no cenário nacional, após a Revolução de 1930. O senso comum da época orientava investir em Ciências Sociais com vistas a formar quadros técnicos e políticos para modernizar o país. Foi assim no Rio de Janeiro (Almeida, 2001), em Minas Gerais (Arruda, 2001; Bastos, 2006, p. 251-268; Lamounier, 1982) e não foi diferente em São Paulo (Limongi, 2001; Miceli, 2001b; Peixoto, 2001). Mas alguns fatores contribuíram para a emergência de uma cultura humanística mais desinteressada, distante da política e dos imperativos utilitários, na FFCL.

Em primeiro lugar, os paulistas estavam distantes do poder central, insulados das instabilidades e imperativos imediatos da cena política. No Rio de Janeiro, embora a Universidade do Distrito Federal e a Faculdade Nacional de Filosofia tenham sido concebidas em linhas parecidas com as da USP, contando com rico apoio intelectual, houve problemas para se estabelecerem em função da dependência do poder político. Isso se manifestou em várias frentes, como nos vínculos de seus dirigentes, que acabaram vulneráveis. Na UDF, por exemplo, Anísio Teixeira, seu mentor, defendia o prefeito Pedro Ernesto. Com sua queda, Anísio foi alijado da UDF, enfraquecendo os intelectuais a ele ligados e seu projeto universitário (Almeida, 2001, p. 234). O modelo de universitário era objeto de disputa política, fortemente afetada pela ideia da construção do "espírito nacional” (idem, p. 235). Assim, as intempéries da política afetavam a estabilidade institucional e, ao mesmo tempo, o conteúdo da produção intelectual dependia, ao que parece em grau apreciável, de orientações políticas e da ocupação de cargos, como integralistas (San Thiago Dantas, Thiers Martins Moreira, etc.) e apoiadores do Estado Novo (Oliveira Vianna, Francisco Campos, etc.) (Almeida 2001, p. 235; Miceli 2001b). Assim, por um lado, a institucionalização encontrou mais obstáculos, por outro, a reflexão social dependia da construção de um "projeto nacional”.

Em segundo lugar, Miceli (2001a, p. 21) sugere que a industrialização e a urbanização, em São Paulo, desencadearam uma diferenciação das elites dirigentes, induzindo a formação de um sistema de oferta e de demanda cultural. Forma-se uma fração de empresários culturais, como a família Mesquita, disposta a investir em cultura, favorecendo a criação de novas ocupações e grupos em condições de aspirar à obtenção de títulos acadêmicos. Tem-se também a forte e crescente influência francesa sobre a elite paulistana, a concepção de atraso cultural e a derrota de 1930 (Peixoto, 2001, p. 483), bem como condições para a criação de instituições dedicadas ao cultivo "desinteressado" da cultura, isto é, à contemplação e à reflexão sem aplicações imediatas. A defesa da "ciência pura" e da "ambição desinteressada", da "cultura pela cultura”, mostra-se explícita em diários dos idealizadores da Faculdade, bem como de franceses e catedráticos entre 1930 e 1950 (Pulici, 2007, p.102-103). Tem-se, assim, à imagem francesa, a formação de um campo de produção cultural mais autônomo do que em 
outras partes do país. A produção intelectual passa a circunscrever-se em um ambiente acadêmico autóctone, que passa a responder aos imperativos dos pares (Arruda, 1995).

A “missão francesa” é um corolário dessas circunstâncias e estabelece o modelo de reflexão "desinteressada", preconizado pelos idealizadores. A missão consistiu na vinda de aproximadamente 29 professores franceses, entre historiadores, cientistas sociais, geógrafos, filósofos e economistas, sobretudo entre 1934 e 1949 (Peixoto, 2001, p. 486), alguns dos quais vieram a ocupar cátedras, imprimindo forte marca da tradição humanística francesa.

Entre 1949 a 1969, a docência e a pesquisa organizavam-se em torno de cátedras. As cátedras foram herança da Coroa Portuguesa, inspirada, por sua vez, no modelo universitário francês, consistindo em unidades de ensino baseadas em um professor dotado de autonomia para definir o conteúdo a ser ensinado e os meios para tal (Lopes; Faria Filho; Veiga, 2003, p. 153). Trata-se, assim, de um modelo personalista, enraizado na Academia Platônica (386 a.C.) e na figura da autoridade filosófica, que passou a se institucionalizar a partir de então. Na FFCL, as cátedras organizavam os cursos de graduação e conferiam títulos como o de doutorado, embora não houvesse um sistema de pós• graduação. Sociologia I e II organizaram o curso స్ํ de "Ciências Sociais e Políticas" (1934-1941), ঠ renomeado "Ciências Sociais" a partir de 1941, por imposição federal (Quirino, 1994, p. 337).

Entre os franceses, Paul Arbousse-Bastide e Roger Bastide foram os mais importantes para a Sociologia da USP. Arbousse-Bastide (1899-1985) formou-se em Filosofia pela École - Normale Supérieure e foi professor da mesma disciplina antes de vir ao Brasil. Foi aluno de Georges Dumas (1866-1946), médico e psicólogo francês de formação humanística e um dos principais responsáveis pela organização da primeira missão francesa ao Brasil (Peixoto, 2001, p. 483). Na FFCL, Arbousse-Bastide passou a presidir a cátedra de Sociologia I, onde ficou de 1934 a 1940, enquanto Claude
Lévi-Strauss (1908-2009), então um eminente etnólogo interessado em tribos brasileiras, presidiu Sociologia II entre 1934 e 1937 (Quirino, 1994). A forte orientação durkheimiana e o foco em docência da missão francesa, típico da tradição humanística daquele país (Peixoto, 2001, p. 525), induzem atritos entre Arbousse-Bastide e Lévi-Strauss, então em crescente afastamento do funcionalismo durkheimiano e mais dirigido à pesquisa de campo (Jackson, 2007b). Assim, Lévi-Strauss se afasta da USP e Roger Bastide assume a cátedra.

Roger Bastide (1898-1974) formou-se em Letras pela Sorbonne. Chegou ao Brasil em 1938, onde assumiu a cátedra de Sociologia II. Ali ficou até 1940, quando se transfere para Sociologia I, substituindo Arbousse-Bastide que, no mesmo ano, assumira a recém-criada cátedra de Política. Fernando de Azevedo, formado em Direito e mentor da sociologia cultural da USP, assumiu Sociologia II, ali ficando até 1964. Bastide permaneceria em Sociologia I até retornar à França, em 1954. Com eles, transmitiu-se às Ciências Sociais da USP a concepção de conhecimento puro, não utilitário, típico da cultura humanística parisiense (Limongi, 2001, p. 262; Peixoto, 2001).

A cultura de reflexão desinteressada não foi o único traço das Ciências Sociais então institucionalizadas. O curso seguia a tradição sociológica francesa e tinha forte feitio filosófico, "teórico" e "geral" (Limongi, 2001, p. 263), e incorporava a literatura como fonte de conhecimento social (Pulici, 2007, p. 105-112); Bastide, por exemplo, chegou a escrever sobre a "Poesia como Método Sociológico" (Queiroz, 1983 apud Pulici, 2008, p. 35). Além de ministrar um curso de Estética, Arbousse-Bastide discutia a clássica questão da possibilidade de uma ciência da sociedade - o estatuto da Sociologia como ciência não era consenso no curso (Quirino, 1994) -, o que viria a ser um dos motivos da guinada "cientificista" de Florestan. Fernando Henrique Cardoso afirmou que a formação, nos dois primeiros anos do curso, em fins da década de 1940, era filosófi- 
ca, com o destaque de Kant, Descartes, Bergson e Freud (Bastos et al., 2006, p. 68). O domínio filosófico e funcionalista não era total; Roger Bastide, em particular, apreciava a psicologia social norte-americana e lecionava autores como George Herbert Mead. Entretanto, assim como na França, a atividade intelectual baseava-se em ensino e leitura. Faltavam verbas para a pesquisa empírica, que era conduzida nas horas vagas, em particular por Bastide (Peixoto, 2001, p. 527).

Esse quadro permaneceu até os anos 1950, quando, em 1954, Florestan Fernandes assume Sociologia I, com o retorno de Bastide à França.

A ascensão de Florestan promove fortes transformações na USP. Logo na década de 1950, Florestan aumenta o espaço de autores mais ligados à Sociologia e torna a formação sociológica mais abrangente. Seus cursos versam principalmente sobre Durkheim, Mauss, Mannheim, Simiand, René Maunier, Lévy -Bruhl, Marx, Engels, Weber, Freyer e a Escola de Chicago. Florestan engaja-se para instituir um modelo mais científico de atividade intelectual - à imagem do que se fazia na Escola Livre de Sociologia e Política (Limongi 2001, p. 271), onde fez o mestrado, defendido em 1947. Acusa o baixo grau de especialização das Ciências Sociais brasileiras, passando a distinguir "professor" de "cientista", afirmando que a universidade brasileira não favorecia o segundo (Melo, 2006, p. 30). Ataca o aristocratismo da Faculdade de Filosofia em vários sentidos. Cita, por exemplo, o desprezo pelo ensino elementar, como a proibição tácita de consulta a manuais e dicionários, privilegiando estudantes previamente expostos à cultura erudita ${ }^{10}$;

${ }^{10}$ Por exemplo: "No primeiro semestre, estudamos Sociologia Sistemática, com base no Homem e sociedade, a coletânea do Fernando Henrique e Octavio Ianni. No segundo semestre, estudamos Sociologia Diferencial, passando por Durkheim, Tönnies, Marx, Hans Freyer. Luiz Pereira era um excelente professor, embora o curso fosse muito difícil, com alta porcentagem de reprovação. Já na primeira aula ele introduzia a noção de práxis de Sartre. Lembro que alguns calouros acharam que a aula fosse trote. Luiz era baixinho, magrinho, falava rápido e tinha uma aparência muito jovem, o que facilitava a confusão. Eu fiquei entusiasmado, pois era mais maduro, tinha tido dois anos de universidade e conhecia a Questão de método de Sartre, o livro de Lucien Goldmann sobre Ciências Humanas etc." (Sallum Junior 2006, apud Bastos et al., 2006, p. 272). as aulas em francês; a atenção excessiva sobre o "aspecto teórico do trabalho"; o culto à figura do gênio criador, isto é, o pensador de "ambição intelectual muito abstrata [...] talvez até excessiva" e desejoso de "dar uma contribuição de significado maior"; o baixo interesse na definição clara de temas de trabalho e de orientação profissional (Bastos et al., 2006, p. 14-19). O ensaísmo é um alvo especial:

O que é construir esta linguagem [acadêmica da Sociologia]? É diferenciar a linguagem sociológica da literatura. Florestan tem até um texto onde teoriza sobre a questão. Ele diz que o ensaio, por isto é que ele não escrevia ensaio, é a forma literária de escrever do estamento, o estilo do estamento, o estilo da oligarquia. E que a ciência não podia seguir a mesma linguagem. É claro que ele não tinha tido uma formação que lhe permitisse ser um estilista e escrever literariamente bem, porque isto pressupõe todo um processo pelo qual não tinha passado. (Arruda 2006, apud Bastos et al., 2006, p. 365)

Em contrapartida, Florestan incentiva a especialização dos papéis, formando o professor, que "era a solicitação maior", o investigador e o técnico. Estimula a formação de pesquisadores atuando em conjunto e a instrução empírica (Bastos et al., 2006, p. 20-21) - embora, na prática, o trabalho tenha continuado em boa medida individual; a integração se dava mais pela coordenação dos temas (Prandi 2006, apud Bastos et al., 2006, p. 301-302; Vianna 2006, apud Bastos et al., 2006, p. 168). Isso ocorre, sobretudo, a partir da formação do projeto Economia e sociedade no Brasil, na década de 1960.

Em suma, sem propor uma ciência social "empiricista” e banir a reflexão teórica, Florestan condena um aristocratismo cultural típico dos intelectuais precursores, adaptado, na Sociologia da USP, à reflexão desinteressada, distanciada de imperativos políticos. Com Florestan a figura do scholar cria raízes na USP. Soci-

Sobre a importância do capital cultural herdado nas Ciências Sociais da USP, conferir as informações biográficas nas entrevistas de Sergio Miceli, Gabriel Cohn, Luiz Werneck Vianna, Maria Arminda do Nascimento Arruda e José Vicente Tavares dos Santos (apud Bastos et al., 2006), para mencionar os principais. 
ólogos como Juarez Brandão Lopes, Reginaldo Prandi, José Carlos Durand, Ricardo Abramovay, entre outros, exemplificam esse modelo.

A conquista de Sociologia I por Florestan pressionou humanistas reunidos em torno de Sociologia II e causou fortes conflitos. ${ }^{11}$ Ela era então presidida por Fernando de Azevedo, eleito membro da Academia Brasileira de Letras em 1967, e a ela se vincularam Maria Isaura Pereira de Queiroz, Antonio Candido, Azis Simão e Rui Coelho (este assumiria a cátedra a partir de 1964). A ascensão de Florestan levou membros das cátedras a se transferirem para Literatura e Estética (Pulici 2007, p. 99-100). Maria Arminda do Nascimento Arruda afirma:

[Em 1968] Permanecia o domínio da cadeira de Sociologia I, tudo o mais parecia ilegítimo fora dela. Eu nunca fiz um curso com a professora Maria Isaura Pereira de Queiroz, por exemplo. O professor Ruy Coelho era considerado um nefelibata. (apud Bastos et al., 2006, p. 356)

A partir da década de 1970, entretanto, parte da geração seguinte renovaria a tradição humanística da USP. Por um lado, José Arthur Giannotti investe e divulga reinterpretações filosóficas das "obras de infância” de Marx, sobretudo por Lukács, Sartre e Goldman, em abordagem fortemente idealista, o que seria condenado por Florestan (Cardoso 2006, apud Bastos et al., 2006, p. 77). Por outro, a nova จ geração constrói um importante programa em Sociologia da Cultura e dá alento aos estudos ڤं literários, com figuras de destaque como Mais ria Arminda do Nascimento Arruda, Gabriel 京 Cohn, Renato Ortiz e Sergio Miceli. O apreço $\stackrel{\text { L }}{\circ}$ pela cultura e o culto à erudição - manifestos

$\stackrel{\infty}{\wedge}$ na obsessão pelo julgamento ${ }^{12}$, no destaque ao $\dot{a}$

of ${ }^{11} \mathrm{O}$ trabalho mais detalhado e abrangente sobre o tema $\checkmark$ é o de Pulici (2008), que também faz um apanhado das $>$ publicaçóes dos principais membros das cátedras, maniثิ festando as posições intelectuais de cada um.

${ }^{12}$ Conferir, em particular, as entrevistas de Octavio Ianni, Gabriel Cohn e Renato Ortiz (Bastos et al., 2006). Os exemplos se multiplicam pelos textos. Destacamos a distinção entre "iluminados" e "formiguinhas" por Cohn (Bastos et Uु al., 2006, p. 125); a exaltação do conhecimento "planetário" por Miceli (Bastos et al., 2006, p. 241), dos pensadores franceses do século XX e sua recorrência a grandes expoentes para descrever o estado de uma disciplina; a defesa de um modelo de formação escolástico (Arruda 2006, talento individual, na valorização da erudição, no apreço pelo livro, no destaque à forma - não descurariam da pesquisa empírica e de uma clara identidade profissional: sem abandonar o estilo literário, o ensaio teórico e a reflexão pura, não utilitária, o modelo humanístico uspiano tornou-se mais erístico e profissional.

A sociologia da USP, assim, oscilou entre o modelo humanístico e o científico - embora aquém dos critérios de cientificidade do empirismo anglo-saxão preconizados pela Ciência Política. Métodos estatísticos, em particular, continuariam alheios, mesmo sob Florestan ${ }^{13}$ (2006, apud Bastos et al., 2006, p. 18).

\section{Efeitos sobre a Ciência Política brasileira}

Um dos principais efeitos foi inibir o estudo da política institucional e a concomitante institucionalização da Ciência Política. ${ }^{14}$ Outro efeito importante foi instalar tradições societais na Ciência Política. As disciplinas permanecem institucionalmente próximas em virtude da organização do campo acadêmico baseado no conceito de Ciências Sociais, no qual a Sociologia é dominante, estimulando o florescimento societal na Ciência Política: (i) as disciplinas permanecem agremiadas nos cursos de graduação; (ii) a Ciência Política permanece dependente da Anpocs - só em meados da década de 1990 a ABCP passaria a atuar efetivamente, tornando-se capaz de influen-

apud Bastos et al., 2006, p. 368); a exaltação da figura do sociólogo feito intelectual total por José Vicente Tavares dos Santos (Bastos et al., 2006, p. 387-388), e por aí vai.

${ }^{13}$ Convidado, no início da década de 1950, para ser assistente na cátedra de Estatística, Florestan recusou afirmando que "não tinha condições nem talento".

${ }^{14}$ Nesse sentido, o caso brasileiro assemelha-se ao italiano. Pasquino (1982) sugere a heteronomia intelectual da Ciência Política em relação à Sociologia como uma das principais causas da fraqueza das áreas e abordagens dedicadas à política institucional, inibindo a institucionalização da Ciência Política. A carreira de Sartori é mencionada por exemplificar a relacão entre o foco sobre instituições políticas e autonomia da Ciência Política (idem; Arruda, 1995, p. 167) - também encontrando paralelo no caso brasileiro, em que o grupo de cientistas políticos mineiros e cariocas elege como objeto legítimo e ressaltam a autonomia da política institucional justificando a autonomização da Ciência Política brasileira. 
ciar a estrutura da produção. ${ }^{15}$ Isso permite a migração de sociólogos e de temáticas e abordagens sociológicas para o campo da Ciência Política. A proximidade institucional também favorece o intercâmbio intelectual - permitindo inclusive o influxo de influências filosóficas disseminadas nas ciências sociais. Assim, diferentes definições de "político" se estabelecem na Ciência Política. A disciplina reagiria dirigindo os mecanismos de estratificação para privilegiar as tradições politológicas e "científicas" e fundando programas de pós-graduação específicos, resguardando e estimulando sua autonomia.

Os seguintes efeitos são também dignos de nota:

- Ao mesmo tempo em que inibiu a autonomização da Ciência Política, estabeleceu um campo acadêmico relativamente autônomo, sem o qual ela não existiria.

- Introduziu um modelo mais profissionalizado de atividade intelectual e, ao mesmo tempo, reproduziu elementos do modelo humanístico mais tarde incorporados à Ciência Política.

- A tradição societal estimulou a incorporação de abordagens sociológicas bastante diversas na Ciência Política, como interacionismo simbólico, memória e imaginário, praxiológica, entre outras.

\section{CIÊNCIA POLITOLÓGICA: o eixo UFMG - luperj}

A visão favorável a uma Ciência Política institucional e intelectualmente autônoma foi forjada na trajetória do grupo de cientistas políticos mineiros e cariocas responsáveis pela fundação de programas de pós-graduação em Ciência Política na UFMG e no Iuperj, ${ }^{16}$ esten-

15 Atualmente, aliás, há um importante periódico com esse propósito, Brazilian Political Science Review, fundado em 2007.

${ }^{16}$ Entre alguns de seus principais expoentes, tem-se: Wanderley Guilherme dos Santos, Fábio Wanderley Reis, Bolívar Lamounier, Antônio Octávio Cintra, Simon Schwartzman, Amaury de Souza, Edmundo Campos Coelho, Eli Diniz, Olavo Brasil de Lima Jr., Renato Boschi, Teotônio dos dendo-se, então, a outros centros importantes, como UFRGS (1973), USP (1974) e UFPE (1982) e disseminando-se nos anos $1990 .{ }^{17}$

Deslocados no campo das Ciências Sociais e influenciados por um modelo norte-americano de Ciência Política, mineiros e cariocas mostram-se mais sensíveis à política institucional e introduzem uma concepção mais ortodoxa de ciência, entrando em choque com o formalismo jurídico, o "sociologismo" e o caráter "pré-científico" de boa parte das ciências sociais brasileiras, reunindo, assim, tradição politológica e científica em uma visão disciplinar que destacaria e institucionalizaria a Ciência Política no Brasil, catalisando a autonomia institucional e intelectual e semeando os princípios que hoje estruturam o campo.

\section{Gestação da visão politológico-científica}

Entre 1959 e 1968, Fábio Wanderley Reis, Bolívar Lamounier, Antônio Octávio Cintra, Amaury de Sousa, Simon Schwartzman, Renato Boschi, entre outros, graduam-se em Sociologia e Política na Faculdade de Administração e Ciências Econômicas (FACE) da UFMG. A atração por um modelo de atividade intelectual mais profissionalizado e a atenção pela política institucional desenvolve-se desde cedo. Em primeiro lugar, o curso é elaborado com vistas à formação de elites responsáveis por modernizar a economia mineira. Por esse motivo, é carregado de disciplinas jurídicas e econômicas, além da presença de Estatística e Matemática, o que era incomum nos cursos vinculados a faculdades de Filosofia (Arruda, 2001, p. 307-318). Houve, é claro, resistência interna de grupos "antiacademicistas", em geral militantes marxistas já adaptados às releituras filosóficas. Os futuros cientistas polí-

Santos, Vinicius Caldeira Brandt, Herbert José de Souza, Ivan Ribeiro, Élcio Saraiva, Maurício Cadaval, José Murilo de Carvalho e Vilmar Faria.

${ }^{17}$ Para uma listagem dos programas de pós-graduação fundados até 2005, consultar Trindade (2007, p. 163). Para dados atualizados e detalhes sobre a expansão da pós-graduação, ver Marenco (2015). 
ticos, ao contrário, incorporam os propósitos profissionalizantes do curso. Esses propósitos se coadunam com o sistema de bolsas da FACE, monopolizado pelos futuros cientistas políticos. De caráter altamente competitivo e semiprofissionalizado, o regime de bolsas exerce um forte estímulo para a profissionalização de suas carreiras acadêmicas (Arruda, 2001, p. 304; Miceli, 1993, p. 59; Oliveira; Ferreira; Castro 1998, p. 359-363).

O regime de bolsas, a cultura técnica e afinidades relativas à origem social de "classe média” gerariam uma forte coesão e autoconsciência (Keinert; Silva, 2010, p. 79, 83). Há, assim, uma negação da militância e uma receptividade latente ao modelo do scholar norte-americano, especialista e profissionalizado. Ao mesmo tempo, os mineiros são expostos, desde a graduação, a estudos partidários e eleitorais (Oliveira; Ferreira; Castro, 1998, p. 364), favorecendo a atenção sobre as instituições políticas. Tudo isso contribuiu para o desenvolvimento de disposições que floresceriam com a pós-graduação na Faculdade Latino-Americana de Ciências Sociais (Flacso) e nos Estados Unidos, agregando tradição politológica e científica em um único modelo.

Outro fator relacional de importância é o conflito, em parte denegatório, com o grupo de ๑ Orlando de Carvalho. Mineiros se interessam ลั. por instituições políticas, objeto então monoФं polizado pelo grupo de Orlando de Carvalho, da Faculdade de Direito, editor da Revista Brasileira de Estudos Políticos (RBEP), na qual, já na década de 1950, são publicados trabalhos sobre partidos e eleições (Lamounier, 1982, p. 416). Sob a óptica do Direito Constitucional, - esses trabalhos são acusados de "formalistas" e "conservadores" pelos futuros cientistas políticos (Forjaz 1997, p. 15-16; Arruda 2001, p. 329), ao mesmo tempo em que, não obstante, chamam sua atenção para a política institucional $^{18}$ (Lamounier 1982, p. 417-418). O estudo de instituições políticas deveria ser depurado

${ }^{18}$ Nesse sentido, Lamounier reconhece afinidades entre o neoinstitucionalismo e a abordagem de Orlando. do formalismo jurídico. Faltavam as abordagens adequadas, descobertas na pós-graduação.

\section{Política e ciência da política}

O afastamento da militância não quis dizer que os cientistas políticos mineiros se desinteressassem pela intervenção. Ao contrário de Veiga (1987), Forjaz (1997, p. 11) e Keinert e Silva (2010, p. 86-87), sugerem que as motivações técnicas do curso também teriam incitado atração pela intervenção, ${ }^{19}$ mas fora dos parâmetros da militância política dos pares. A prática do grupo era orientada pelo regime de estudos semiprofissional. Ocorre que, mais tarde, com a experiência na Flacso e nos EUA, esse interesse passaria a ser cultivado através da atividade científica - isto é, tratarse-ia de fornecer diagnósticos "realistas" sobre os mecanismos da democracia brasileira, no intuito de melhorá-los (Keinert Silva, 2010, p. 95), modelo compatível com o do "politólogo técnico", que emergiria internacionalmente a partir da década de 1990, associado ao neoinstitucionalismo e ao comprometimento com a democracia (Lessa, 2011, p. 47).

\section{A experiência na Flacso: cientificidade e conflito doméstico com a Sociologia}

O contato com a Ciência Política norte-americana, através da pós-graduação na Flacso, é decisiva para o estabelecimento de uma visão disciplinar centrada nas tradições politológicas e científica, já estabelecida nos Estados Unidos ${ }^{20}$ (Carvalho 1998, apud Oli-

${ }^{19}$ Talvez as duas interpretações não sejam incompatíveis. Enquanto Veiga (1987) refere-se especificamente ao período de graduação na FACE, Forjaz (1997) e Keinert e Silva (2010) referem-se também ao período de pós-graduação, quando há a referida simbiose entre intervenção e ciência, havendo, talvez, mais uma diferença cronológica entre os diagnósticos do que um contraste substantivo. Há também heterogeneidade no grupo, com Fábio Wanderley Reis demonstrando uma posição mais acadêmica e Bolívar Lamounier mais receptividade à intervenção.

20 "De Minas, foram Fábio Wanderley, Bolívar Lamounier, Simon Schwartzman, Amauri de Souza. Do Rio, Wander- 
veira; Ferreira; Castro 1998, p. 365). A atuação no campo das ciências sociais com o objetivo de transformar a estrutura da produção iniciase no retorno da Flacso, quando se estabelece uma oposição sistemática, em primeiro momento às abordagens humanísticas. Antes de se destacar institucionalmente da Sociologia e fundar o Departamento de Ciência Política (DCP), os mineiros atuam ainda dentro do curso de Sociologia e Política. Fábio Wanderley Reis e Antônio Octávio Cintra retornam da Flacso em 1963 e 1964, como professores da FACE, iniciando a "modernização do curso", que envolveria "aposentar a tradição europeia" e substituí-la pela "tradição anglo-saxã". Peter Heintz, Galtung, Blalock e Popper foram incluídos na ementa do curso, considerados pelos reformistas como proponentes de uma "sociologia científica” (Veiga, 1987, p. 15). Antônio Octávio Cintra, em uma espécie de acerto de contas com o que parece considerar como um excesso de juventude, ao referir-se à experiência da Flacso, falaria em "lavagem cerebral" e "muito neopositivismo", ao qual estavam "predispostos" (Arruda, 2001, p. 321). José Murilo de Carvalho ressalta a orientação matemática de Johan Galtung, discípulo de Lazarsfeld e professor na Flacso. Galtung foi responsável pela seleção dos pós-graduandos, tendo requisitado que José Murilo resolvesse um problema de álgebra. A falha no teste lhe custaria a bolsa (Oliveira; Ferreira; Castro, 1998, p. 362). Em outras palavras, há a adesão a um modelo de atividade intelectual fundado no empirismo epistêmico e a abordagens desenhadas em torno do positivismo lógico ${ }^{21}$ Kaplan (1964, p. 36).

Nesses termos, é como se a experiência na Flacso desabrochasse disposições formadas durante a graduação, direcionando mineiros a uma adesão mais completa e sistemática a uma visão mais ortodoxa de ciência. Repare-

ley Guilherme, César Guimarães, Carlos Hasenbalg. Posteriormente, foram também Renato Boschi, Elisa Reis, Olavo Brasil, os três de Minas".

${ }^{21}$ No sentido especificado por Kaplan. se como, durante a experiência na Flacso, essa tradição ainda se associa à Sociologia. Cientificidade vem antes do afastamento da Sociologia. A guinada decisiva para a Ciência Política ocorreria durante e após o doutoramento nos Estados Unidos, quando o empirismo epistêmico se amalgama com tradição politológica.

Gurvitch foi o principal autor no curso da FACE (Veiga, 1987, p. 15). Docente na cátedra de Política na USP em 1947, com Arbousse-Bastide e outros, contribuiu para conferir um caráter "sociologizante" aos estudos políticos na USP (Quirino, 1994). As preocupações temáticas eram parecidas: o problema do conhecimento, desenvolvimento e leitura dos clássicos, praticando-se algo entre uma concepção societal de poder e sociologia pura. É como se a estrutura do conflito, mais tarde travado em nível nacional, fosse antecipada no meio da UFMG durante a década de 1960: uma sociologia humanística infensa à política institucional, um marxismo societal e teoricamente orientado e futuros cientistas políticos implantando uma disciplina politológica e científica. Essa estrutura fica mais clara depois da criação do Departamento de Ciência Política, quando os quadros mais "científicos" da FACE migram para a Ciência Política: o leque de abordagens que permanece e se estabelece no curso de Sociologia e Política manifesta a sociologia humanística então dominante (Veiga 1987, p. 25).

O que se estabelece durante a década de 1970 é o retrato da tradição societal instituída em outros centros, como na própria USP e, mais tarde, na Unicamp: formação do Estado, capitalismo brasileiro, relações de classe e marginalidade urbana, (idem, p. 26). Em paralelo, em meados dos anos 1960, as preocupações com "metodologia" deslocam-se para a "epistemologia", atribuindo-se mais peso à construção de teoria do que à conduta da pesquisa empírica. 
A consolidação de uma nova visão disciplinar: a experiência norte-americana e o conflito com as tradições humanísticas e societais

O doutoramento nos Estados Unidos é o prolongamento lógico da experiência na Flacso. ${ }^{22}$ A experiência nos Estados Unidos sintetiza disposições assimiladas desde a graduação. Em primeiro lugar, há uma identificação com um modelo de atividade intelectual baseado na figura do scholar, no trabalho coletivo, na valorização de periódicos, na leitura extensiva, na atenção à evidência, no rigor empírico, entre outras propriedades típicas do modelo científico. Em segundo lugar, desenvolve-se uma formação epistemológica mais sólida dentro dos parâmetros do positivismo lógico e aprendem-se métodos quantitativos ainda inéditos no Brasil. Além disso, tem-se contato com abordagens que privilegiam a política institucional, operando um refinamento teórico apropriado às necessidades intelectuais e aos anseios políticos do grupo. Dispõe-se de métodos e teorias científicas sobre a política institucional, cujo principal traço distintivo em relação à Sociologia política praticada no Brasil seria estudar e, ao fazê-lo, considerar fatores internos em temas como a transformação no sistema de governo (e. g., as bases politológicas do autoritarismo), elaboração de políticas públicas, estrutura do ๗ sistema partidário, determinantes do comportamento político, entre outros.

Autoconsciente e mobilizado para instituir abordagens mais "científicas" e temas propriamente políticos no campo das ciên$\overbrace{\infty}^{\infty}$ cias sociais, o grupo não se encaixa no espaço \& acadêmico estabelecido. Em primeiro lugar, a ôे estrutura intelectual estabelecida responde a

${ }^{2}$ Fábio Wanderley Reis (University of Harvard), Wanderley Guilherme dos Santos (Stanford University), Simon Schwartzman (University of California, Berkeley), Antonio Octávio Cintra (Massachusetts Institute of Technolo-

gy), Bolívar Lamounier (University of California, Los An-

G geles), Renato Boschi (University of Michigan), Gláucio

Ary Dillon Soares (Washington University St. Louis) e José

Murilo de Carvalho (Stanford University), para mencionar

os principais. Com a exceção de Gláucio, que se doutora em Sociologia, todos o fazem em Ciência Política. princípios diametralmente opostos - e os grupos a ela associados posicionam-se de forma antitética (societais, humanísticos, teóricos, ensaísticos, polímatas), enquanto, ao mesmo tempo, monopolizam as instituições de ensino e pesquisa e controlam as associações profissionais. Em segundo, ainda não existe a posição do cientista político profissional. Assim, o choque com a estrutura estabelecida e as possibilidades de inserção acadêmica e de produção intelectual, abertas pelo terreno ainda inexplorado da Ciência Política no Brasil, estimula o grupo mineiro-carioca a fundar e a ocupar um espaço institucional dedicado à Ciência Política - e a defini-la em função de sua visão disciplinar. As tradições politológicas são particularmente adequadas: tem-se, afinal, um objeto específico, autônomo e favorável à defesa da democracia. Com o modelo científico e a figura do scholar, também se combateria o "obscurantismo" nas ciências sociais.

É assim que o Departamento de Ciência Política é fundado em 1967, seguindo-se a criação do primeiro mestrado em Ciência Política, em 1969. À falta de um aporte financeiro e de possibilidades institucionais de expansão exigidos para acomodar todo o grupo (Arruda, 2001, p. 321, 362-365), boa parte emigra para o Iuperj. No decorrer da década de 1970, transferem-se Simon Schwartzman, José Murilo de Carvalho, Elisa Reis, Olavo Brasil de Lima Jr., Bolívar Lamounier, Edmundo Campos Coelho e Eli Diniz. Fábio Wanderley Reis permanece na UFMG e dirige o crescimento da Ciência Política em Minas, enquanto Wanderley Guilherme dos Santos dirige o Iuperj, ao qual também se filiam Carlos Hasenbalg e Gláucio Ary Dillon Soares. O Iuperj fundaria seu curso de mestrado em 1969.

A inserção institucional do grupo de mineiros e cariocas foi facilitada pela reforma do sistema universitário brasileiro e o vigoroso programa de expansão da pós-graduação, em que as Ciências Sociais, antes pouco consideradas pelas agências governamentais de fomento, passariam a ganhar mais espaço, tanto no 
CNPq, que, em 1964, passara a ser a instituição responsável por formular a política científicotecnológica nacional, como na Capes.

É também na segunda metade da década de 1960 que a Fundação Ford, tendo em vista o cenário político internacional de escalada da influência acadêmica e política do marxismo, implantaria um amplo projeto de financiamento às Ciências Sociais na América Latina e, em particular, no Brasil (Miceli, 1990, 1993, 2001b; Reis, 1993). Desconfiada das tendências ideológicas da Sociologia, a Fundação Ford investe na Ciência Política e a Antropologia, em especial, por se tratar, então, de disciplinas pouco institucionalizadas no Brasil. Tratou-se de uma oportunidade para exportar modelos norte-americanos de atividade intelectual e suas afinidades político-ideológicas (Miceli, 1990, 1993) a campos acadêmicos incipientes, embora não tenha exercido pressão para influenciar os grupos e instituições financiados ${ }^{23}$, em parte, como sugere Miceli, pela orientação mais "liberal" do escritório latino-americano, distinto da matriz mais "conservadora" ${ }^{24}$ (Faria; Costa, 2006). Os filtros ideológicos, é claro, atuam logo no instante da seleção, excluindo os casos normativamente mais radicais. Sem a expansão da pós-graduação, o apoio da Fundação Ford e o próprio cenário político internacional, o eixo UFMG-Iuperj provavelmente enfrentaria mais dificuldades para estabelecerse, possivelmente atrasando a institucionalização da Ciência Política e o estabelecimento das tradições politológica e científica.

Agora em nível nacional, sucedem intensos conflitos entre a visão politológicocientífica, de mineiros e cariocas, de um lado, e tradições societais e humanísticas, de outro, em particular concentradas no marxismo praticado pela autodenominada "escola paulista". Além do marxismo, também seriam criticadas orientações muito "sociologizantes", como o

${ }^{23}$ Veja-se, por exemplo, o caso do Cedec, um centro de pensamento de esquerda, criado e sustentado com o financiamento da Ford.

${ }^{24}$ Uma análise dedicada à atuação da Fundação Ford pode ser consultada em. funcionalismo e o estruturalismo franceses. Com o marxismo, o maior problema é de natureza epistemológica, considerado anticientífico, e pelo exacerbado societalismo.

Funda-se, em 1961, a Revista Brasileira de Ciências Sociais, parte das iniciativas institucionais dos mineiros e o principal veículo no qual passariam a posicionar-se intelectualmente (Arruda, 2001, p. 338-339, 354-356). O conteúdo temático, a distribuição disciplinar e os posicionamentos teórico-metodológicos publicados na Revista sintetizam a dinâmica acadêmica e intelectual das Ciências Sociais em Minas, a trajetória dos cientistas políticos mineiros e prenuncia sua militância intelectual a partir de $1966^{25}$ Arruda (2001, p. 322-360). Em meio às dificuldades do DCP, a Revista encerra suas atividades em 1966 (idem, p. 321), ${ }^{26}$ quando o centro do movimento desloca-se para o Iuperj e, no mesmo ano, é criado o principal veículo de posicionamento acadêmico-intelectual do grupo, o periódico com o sugestivo nome Dados, fortalecendo-se o aporte institucional da visão disciplinar propugnada pelo grupo.

O conflito com a sociologia praticada na USP já se manifesta nos últimos números da Revista, quando os posicionamentos se tornam mais fortes. Em defesa da tradição "científica”, Antônio Octávio Cintra acusa a correlação entre a "ideia de totalidade", o "método dialético" e "métodos qualitativos". O marxismo então praticado representa a antítese do modelo científico preconizado: "interesse objetivo de classe", "falsa consciência de classe", "alienação", "lógica do processo histórico" etc. seriam inobserváveis, construídos de modo a confirmar a teoria independentemente do feedback da realidade, em última instância recorrendose a argumentos anticientíficos, como de autoridade, "dogma de classe", etc. (Cintra 2001, apud Arruda, 2001, p. 356-357). Referindo-se a um "certo marxismo",

${ }^{25}$ Para uma análise aprofundada do contexto e da produção da Revista, consultar Arruda.

${ }^{26}$ Em 1986, a Anpocs passaria a publicar um periódico com o mesmo nome. 
Wanderley Guilherme dos Santos faz eco às objeções de Antônio Octavio Cintra, acusando-o de "escolástico" e caracterizado por "onanismo intelectual", "obsessão definicional" e "fanatismo do dogma”, ou seja, como uma espécie de religião transvestida de ciência social (Santos, 1980, p. 25). Vilmar Faria (2001, apud Arruda, 2001, p. 358) declara falta de "rigor científico" na sociologia brasileira, repetindo a crítica ao "ensaísmo" e o "divórcio entre pesquisa empírica e sistematizações teóricas". Referindo-se aos trabalhos "Empresário industrial e desenvolvimento econômico", de Fernando Henrique Cardoso, "Raízes sociais do populismo em São Paulo", de Francisco Weffort e "A crise do pensamento sociológico”, de Octávio Ianni, Fábio Wanderley Reis clamaria por um "[...] compromisso mais sério com padrões que orientem o trabalho dos estudiosos dos fenômenos sociais em um sentido em que tal trabalho possa ser fonte de conhecimentos e não reiteração indefinida de princípios gerais" (Arruda, 2001, p. 358). Não se trata somente de uma oposição teórico-metodológica, mas uma discordância que alcança diferenças mais fundamentais entre modelos de atividade intelectual.

No que se refere à tradição societal, Wanderley Guilherme dos Santos acusa a falta de trabalhos que considerem a política institucional e, entre os que o fazem, a tendência de desconsiderar sua autonomia. O autor localiza ambas as abordagens na tendência "globalizante" das Ciências Sociais então em prática (idem, p. 18). Dirigindo-se ao alvo principal, a USP, Bolívar Lamounier segue no mesmo sentido, criticando tanto o predomínio da tradição s societal nos estudos políticos, extensível ao marxismo, como a relativa escassez deles (Lamounier, 1982, p. 417-418, grifos no original).

Um debate interno ao grupo de mineiros e cariocas expressa a importância da questão da "autonomia do político" e do foco sobre a política institucional, ao mesmo tempo em que mostra que ela não era consensual. Nesse sentido, Simon Schwartzman representa uma posição mais ortodoxa, enquanto Gláucio Ary
Dillon Soares, sociólogo, mostra-se mais favorável à consideração de objetos e fatores societais em seus trabalhos. Em curioso diálogo entre ambos, Simon mostra certa consternação com a "sociologia política” praticada por Gláucio. Ao referir-se ao trabalho Estado e partidos políticos no Brasil, de Maria do Carmo Campello de Souza, exclamaria "É contra a gente!", clamando por explicar "o político pelo político". A posição era clara: desconsiderar a autonomia das instituições políticas equivaleria a não produzir Ciência Política (Soares 2008, apud Gomes; D’Araújo, 2008, p. 340-341).

\section{Efeitos sobre a Ciência Política brasileira}

Entre os principais efeitos dessa visão disciplinar, vale destacar:

- Ao fundar os primeiros programas de pósgraduação específicos, dá início à autonomização institucional e intelectual da Ciência Política.

- É a raiz dos atuais mecanismos de estratificação, que favorecem (i) o estudo da política institucional, (ii) seu tratamento como âmbito autônomo e (iii) uma visão mais ortodoxa de ciência, composta por estudos empíricos, métodos quantitativos, sofisticação estatística, apresentação e teste de hipótese e causalidade.

- Dissemina e define um modelo de atividade intelectual e uma identidade profissional centrados na figura do scholar norte-americano.

\section{CONCLUSÕES}

Mostrou-se que a produção acadêmica dependeu de um conflito entre visões disciplinares, a saber: uma humanística, associada à figura do polímata, uma societal, oscilante entre os modelos humanístico e científico, e outra politológico-científica. As oposições estiveram vinculadas às trajetórias de grupos capazes de institucionalizar suas visões e abor- 
dagens, e essas trajetórias, por sua vez, dependeram das relações de proximidade e distanciamento com outras disciplinas, com o campo intelectual e com o campo político. Cada visão produziu efeitos distintos sobre a autonomização da Ciência Política, desestimulando-a ou favorecendo-a, instituindo modelos de atividade intelectual e estimulando o estabelecimento de certas áreas e abordagens na produção da Ciência Política contemporânea.

A visão humanística é responsável pelas áreas e abordagens que orbitam os estilos literário, militante e acadêmico e está vinculada a tradições não politológicas, como a estatal, a societal e a idealista, aderindo a uma concepção de "político" em sentido amplo. ${ }^{27}$ Os proponentes dessa visão tendem a um habitus historicamente construído em torno da figura do polímata; tendem a preferir livros como principal meio de publicação, e mesmo a cultivá-los, dentro da apreciação literária do aucteur; tendem a ser menos favoráveis à especialização temática e teórico-metodológica, a critérios "objetivos" de avaliação (como o Qualis) e favorecem um ethos intelectual mais aristocrático e intervenção política nos parâmetros de uma intelligentsia.

Oriunda, sobretudo, da heteronomia com a Sociologia, a visão societal oscila entre os extremos humanístico e científico, entre o polímata e o scholar, com certo desvio ao polo humanístico. Essa heterogeneidade é encontrada na própria trajetória da "escola sociológica paulista”, que, em um primeiro momento, se estabelece contra a orientação literária e ensaística praticada antes de Florestan e nas demais cátedras, e, mais tarde, converte-se a um marxismo teórico-ensaístico. Também se expressa na relativa proximidade entre o estilo cognitivo erístico e as tradições societais, ao mesmo tempo em que há repulsa por métodos quantitativos, atração por métodos qualitativos e valores intermediários nos demais critérios ortodoxos de cientificidade. Essa visão tem

${ }^{27}$ As distâncias podem ser consultadas com mais detalhes em Leite (2015). como consequência manter vagas as fronteiras entre Sociologia Política e Ciência Política, e é responsável pela forte presença de abordagens e temas tipicamente sociológicos na produção da Ciência Política, como classes, elites, trabalho e movimentos sociais. Em outras palavras, ela favorece a heteronomia intelectual da $\mathrm{Ci}$ ência Política em relação à Sociologia.

Já a visão politológico-científica, intrinsecamente associada à autonomia institucional e intelectual da Ciência Política, define-se pela proximidade com a política institucional e por uma visão mais ortodoxa de ciência, dentro dos parâmetros do empirismo epistêmico, do pragmatismo e do positivismo lógico, privilegiando também a especialização e a profissionalização da atividade intelectual. Estabeleceu-se no campo em estrito comprometimento com a democracia, o que, por vezes, levou (e ainda leva) quadros opostos a criticá-la por restringir-se às instituições políticas "liberais". Esse comprometimento tem uma dimensão normativa (deseja-se que a democracia prospere) e intelectual (acredita-se que as instituições políticas têm autonomia), comprometimento que esteve na base e justificou a autonomização da Ciência Política. No campo de produção, essa visão orbita o estilo erístico e está fortemente associada a critérios mais ortodoxos de cientificidade, como o uso de estatísticas mais sofisticadas e construção de argumentos causais. É também mais favorável a critérios "objetivos" de avaliação, como o Qualis ou a indexação de periódicos em bases internacionais. Nesse mesmo sentido, é a visão mais valorizada pelos mecanismos atuais de estratificação, provavelmente por dirigi-los. Em outras palavras, há uma relação muito próxima entre a trajetória dos grupos, as propriedades da produção e as hierarquias da disciplina, e o estudo sistemático dessas relações pode, além de autoconsciência, conferir mais controle sobre o futuro da Ciência Política, em particular para torná-la, além de diversa, mais democrática.

Recebido para publicação em 15 de abril de 2015 Aceito em 03 de maio de 2016 


\section{REFERÊNCIAS}

ARRUDA, M. A. N. A Sociologia no Brasil: Florestan Fernandes e a "escola paulista". In: MICELI, S. História das ciências sociais no Brasil. São Paulo: Sumaré, 1995. v. 2.

A modernidade possível: cientistas e ciências sociais em Minas Gerais. In: MICELI, S. História das ciências sociais no Brasil. São Paulo: Sumaré, 2001. v.1.

BASTOS, E. R. et al. Conversas com sociólogos brasileiros. São Paulo: Editora 34, 2006

BRANDÃO, G. M. Linhagens do pensamento politico brasileiro. Dados, Rio de Janeiro, v. 48, n. 2, p. 231-269, 2005.

CASTRO, C.; OLIVEIRA, L. L. Entrevista com Luiz Werneck Vianna. Estudos Históricos, [S.1], v. 35, p. 177-191, 2005.

FARIA, L.; COSTA, M.C. Cooperação científica internacional: estilos de atuação da Fundação Rockefeller e da Fundação Ford. Dados, Rio de Janeiro, v. 49, n. 1, p. 159-191, 2006.

FORJAZ, M. C. S. A emergência da ciência política no Brasil: aspectos institucionais. Revista Brasileira de Ciências Sociais, São Paulo, v. 12, n. 35, 1997.

GOMES, A. de C.; D’ARAUJO, M. C. Entrevista com Gláucio Ary Dillon Soares. Estudos Históricos, [S.l], v. 21, n. 42, p. 323-349, 2008.

JACKSON, L. C. Gerações pioneiras na sociologia paulista 1934-1969. Tempo Social, [S.l], v. 19, n. 1, p. 115-130, 2007a.

Tensões e disputas na sociologia paulista (19401970). Rev. Bras. Ciênc. Soc., São Paulo, v. 22, n. 65, p. 33-49, 2007b.

JAGUARIBE, H. "ISEB - Um breve depoimento e uma reapreciação crítica". Cadernos de Opinião, [S.l], n.14, p. 94-110, 1979

KAPLAN, A. The conduct of inquiry. Methodology for behavioral science. San Francisco: Chandler, 1964

KEINERT, F. C.; SILVA, D. P. A gênese da ciência política brasileira. Tempo Social, [S.1], v. 22, n. 1, p. 79-98, 2010.

KUMASAKA, H.; BARROS, L. Entrevista com Evaristo de Moraes Filho. História da Ciência. Campinas: Arquivo Histórico do CLE/UNICAMP, 1988a

Entrevista com professor Hélio Jaguaribe de

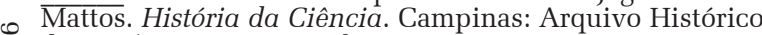
$\because$ do CLE/UNICAMP, 1988b.

j LAMOUNIER, B. A Ciência Política no Brasil: roteiro para um balanço crítico. In: A ciência política nos anos 80 . B Brasília: UnB, 1982. p. 407-433.

œ LEITE, F. O campo de produção da ciência política Lิ brasileira contemporânea: uma análise histórico@ estrutural de seus princípios de divisão a partir de periódicos, áreas e abordagens. 2015. Tese (Doutorado em ¿ Sociologia) - Programa de Pós-Graduação em Sociologia da ¿. Universidade Federal do Paraná, Paraná, 2015.

$\stackrel{\infty}{\wedge}$ LESSA, R. Da interpretação à ciência: por uma história ¿ filosófica do conhecimento político no Brasil. Lua Nova: of Revista de Cultura e Política, São Paulo, n. 82, p. 17-60, 2011.

$>$ LIMONGI, F. A escola livre de sociologia e política em São î Paulo. In: MICELI, S. (Org.). História das Ciências Sociais no Brasil. São Paulo: Sumaré, 2001. v.1. p. 223-255.

$\geq$ LOPES, E. M.; FARIA FILHO, L. M.; VEIGA, C. G. 500 Anos œ de educação no Brasil. Belo Horizonte: Autêntica, 2003.

MARENCO, A. The three "achilles" heels of Brazilian political science. Bras. Political Sci. Rev., Rio de Janeiro, v. 8, n. 3, p. 3-38, 2015

MATOS, F. de. A cadeia secreta: Diderot e o romance filosófico. São Paulo: Cosac Naify, 2013.
MELO, R. W. Sociologia e política acadêmica nos anos 60. São Paulo: Humanitas, 2006.

MICELI, S. A desilusão americana: relações acadêmicas entre Brasil e Estados Unidos. São Paulo: Sumaré, 1990.

. A Fundação Ford no Brasil. São Paulo: Sumaré, 1993.

Por uma sociologia das ciências sociais. In:

$\overline{(O r g}$.) História das ciências sociais no Brasil. São Paulo: Sumaré, 2001a. v. 1.

Condicionantes do desenvolvimento das ciências sociais. In: História das ciências sociais no Brasil. São Paulo: Sumaré, 2001b. v.1.

MILLER, F. Aristotle's political theory. Stanford: Stanford dictionary of philosophy, 2012.

MONDIN, B. Introdução à filosofia: problemas, sistemas, autores, obras. 16. ed. São Paulo: Paulus, 2006.

OLIVEIRA, L. L. Modernidade e questão nacional. Lua Nova: Revista de Cultura e Política, São Paulo, v. 20, p. 41$58,1990$.

; FERREIRA, M.; CASTRO, C. Entrevista com José Murilo de Carvalho. Estudos Históricos, [S.1], v. 22, p. 357377, 1998.

PAPAS, N. "Plato's Aesthetics". In: ZALTA, E. N. et al. (Orgs.) Stanford dictionary of philosophy. Stanford: Stanford University, 2015.

PASQUINO, G. A ciência política italiana: profissionalização lenta e desigual. In: LAMOUNIER, B. A ciência política nos anos 80. Brasília: UnB, 1982.

PEIXOTO, F. Franceses e norte-americanos nas Ciências Sociais brasileiras (1930-1960). In: MICELI, S. História das ciências sociais no Brasil. São Paulo: Sumaré, 2001. v.1.

PULICI, C. De como o sociólogo brasileiro deve praticar seu ofício: as cátedras de sociologia da USP entre 1954 e 1969. Perspectivas, Maracaibo, v. 31, p. 97-120, 2007.

Entre sociólogos: versões conflitivas da "condição de sociólogo" na USP dos anos 1950/60. São Paulo: Edusp, 2008. QUEIROZ, M. I. .P. (Org.). Roger Bastide. São Paulo: Ática, 1983.

QUIRINO, C. Departamento de ciência política. Estud. Av., São Paulo, v. 8, n. 32, p. 337-348, 1994.

REIS, F. W. As ciências sociais nos últimos 20 anos. Rev. Bras. Ciênc. Soc., São Paulo, v. 12, n. 35, 1997.

SANTOS, W. G. A Ciência política na América Latina. Dados, [S.l], v. 23, p. 15-27, 1980.

Roteiro bibliográfico do pensamento político-social Brasileiro (1870-1965). Rio de Janeiro: Oswaldo Cruz, 2002.

SCHWARCZ, L. M.; BOTELHO, A. Pensamento social brasileiro, um campo vasto ganhando forma. Lua Nova: Revista de Cultura e Política, São Paulo, n. 82, p. 11-16, 2011.

TRINDADE, H. Ciências sociais no Brasil em perspectiva: fundação, consolidação e expansão. In: . As ciências sociais na América Latina em perspectiva comparada. 2. ed. Porto Alegre: UFRGS, 2007.

Ciências sociais no Brasil: diálogos com mestres e discípulos. São Paulo: Anpocs, 2012.

VEIGA, L. A trajetória de uma geração de cientistas sociais em Belo Horizonte: imagens de anos nem sempre dourados. In: CONGRESSO NACIONAL DE SOCIOLOGIA, 3., 1987, Porto Alegre. Anais... Porto Alegre: Sociedade Brasileira de Sociologia, 1987.

VILLAS BÔAS, G. A vocação das ciências sociais: um estudo de sua produção em livros do acervo da biblioteca Nacional 1945-1966. Rio de Janeiro: Fundação Biblioteca Nacional, 2007. 


\section{DISCIPLINARY TRADITIONS AND INTELLECTUAL TRADITIONS IN THE TRAJECTORY OF THE BRAZILIAN POLITICAL SCIENCES}

\author{
Fernando Leite
}

This article deals with the role of disciplinary and intellectual traditions in the constitution of Brazilian Political Sciences. It aims to identify the traditions that influenced the perceptions of intellectual groups, sociologists and political scientists responsible for the principles that structured the discipline's current production. From interviews and literature review, we identified traditions and their oppositions. We understand that the adherence and the incorporation of one or another tradition by one of the groups involved depended on their academic trajectories, marked by oppositions oriented in the sense of defining the discipline i.e. defining the legitimate objective of the field and the approaches considered more appropriate to study it. The production depended on three groups and perceptions: (I) humanistic, associated with intellectuals that studied political themes before the institutionalization of the Political Sciences; (ii) academic-societal, associated with the "São Paulo's sociological school"; and (iii) scientific-politico-logical, associated with the group constituted around the UFMG (Federal University of Minas Gerais) and the Iuperj (University Research Institute of Rio de Janeiro), responsible for the institutionalization of the Political Sciences in Brazil.

KEYwords: Brazilian Political Sciences. Social Scientists. Academic productions. Disciplinary traditions. Intellectual traditions.

\section{TRADITIONS DISCIPLINAIRES ET TRADITIONS INTELLECTUELLES DANS LA TRAJECTOIRE DES SCIENCES POLITIQUES BRESILIENNES}

\author{
Fernando Leite
}

L'article traite du rôle des traditions disciplinaires et intellectuelles dans la constitution des Sciences Politiques brésiliennes. L'objectif est d'identifier les traditions qui ont influencé l'opinion des groupes d'intellectuels, de sociologues et de politologues responsables des principes qui ont structuré la production actuelle de cette discipline. Suite aux interviews et références bibliographiques consultées, nous avons pu identifier les traditions et leurs oppositions. Cela nous a permis de comprendre que l'adhésion à telle ou telle tradition et son incorporation par les groupes concernés dépendaient de leurs trajectoires académiques marquées par des oppositions allant dans le sens de la définition de la discipline, c'est-à-dire de la définition de son objet légitime et des approches considérées les plus appropriées pour l'étudier. La production s'est faite en fonction de trois groupes et de points de vue : (i) humaniste, associée aux intellectuels qui étudiaient les thèmes politiques avant l'institutionnalisation des Sciences Politiques ; (ii) académique-sociétale, associée à "l'école sociologique de Sao Paulo"; et (iii) scientifique et politique, associée au groupe formé autour de l'UFMG et de l'Iuperj, responsables de l'institutionnalisation des Sciences Politiques au Brésil.

Mots-clés: Sciences Politiques brésiliennes. Chercheurs en sciences sociales. Production académique. Traditions disciplinaires. Traditions intellectuelles. 
